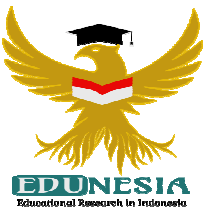

\title{
PENGARUH MODEL PEMBELAJARAN DEEP DIALOGUE/CRITICAL THINGKING (DD/CT) TERHADAP KEMAMPUAN PEMAHAMAN KONSEP SISWA KELAS X SMA
}

\author{
Irma Dhia Saifina; Henra Saputra Tanjung² \\ 1,2Pendidikan Matematika, STKIP Bina Bangsa, Indonesia \\ ${ }^{2}$ Corresponding Email: hnrsaputra@gmail.com, Phone Number : 0813 xxxx xxxx
}

Article History:

Received: Des 21, 2019

Revised: Jan 17, 2020

Accepted: Jan 24, 2020

Published: Jan 30, 2020

\section{Keywords: \\ Conceptual understansding, Deep dialogue/critical thinking.}

Kata Kunci:

Deep dialogue/critical thinking,

Pemahaman konsep.

\section{How to cite:}

Saifina, I.D., \& Tanjung, H.S. (2020). Pengaruh Model Pembelajaran Deep Dialogue/Critical

Thingking

(DD/CT)

Terhadap Kemampuan Pemahaman Konsep Siswa Kelas X SMA. Edunesia : Jurnal Ilmiah Pendidikan, 1 (1): 17-24

\begin{abstract}
This study aims to find out how much a significant influence between the use of deep dialogue/critical thinking learning models on the ability to understand the mathematical concepts of class X students of SMAN 1 Meurebo. The approach taken in this study is a quantitative approach with the entire population of class $X$ SMAN 1 Meurebo and the sample is students of class X MIA1 as a class given a deep dialogue critical learning model. The instrument used in this study consisted of teacher observation sheets, student observation sheets, interview guidelines, and tests. The results showed that there was a significant influence that is $65 \%$ between the deep dialogue critical thinking models of learning towards students' conceptual understanding abilities. After obtaining the values of $a$ and $b$, the linear regression equation is. Based on the results of calculations performed to test the hypothesis applied, the value of $\mathrm{t}$ arithmetic is 4.01 . When compared with a $95 \%$ confidence level or an error rate of $5 \%$ with a degree of freedom $(\mathrm{dk})=24-2=22$ which is 1.72 . It can be seen that $\mathrm{t}$ arithmetic $>\mathrm{t}$ table which is $4.01>1.72$ means $\mathrm{H} 1$ is accepted. That is, if the teacher uses the learning model of deep dialogue critical thinking in the process of teaching and learning, the ability to understand the concept of class $X$ MIA 1 students of SMAN 1 Meurebo on the subject matter of the linear absolute value equation of one variable will be better.
\end{abstract}

Abstrak: Penelitian ini bertujuan untuk mengetahui seberapa besar pengaruh yang signifikan antara penggunaan model pembelajaran deep dialogue/critical thingking terhadap kemampuan pemahaman konsep matematika siswa kelas X SMAN 1 Meurebo. Pendekatan yang dilakukan dalam penelitian ini adalah pendekatan kuantitatif dengan populasi seluruh kelas X SMAN 1 Meurebo dan sampelnya adalah peserta didik kelas $\mathrm{X}_{\mathrm{MIA}}$ sebagai kelas yang diberikan model pembelajaran deep dialogue critical thingking. Instrumen yang digunakan dalam penelitian ini terdiri dari lembar observasi guru, lembar observasi siswa, pedoman wawancara, dan tes. Hasil penelitian menunjukkan bahwa terdapat pengaruh yang signifikan yaitu $65 \%$ antara model pembelajaran deep dialogue critical thingking terhadap kemampuan pemahaman konsep siswa. Setelah didapat nilai a dan b maka persamaan regresi liniernya yaitu $\hat{Y}=38,45+0,52 x$. Berdasarkan hasil perhitungan yang dilakukan untuk menguji hipotesis yang diterapkan maka nilai dari t hitung yaitu 4,01. Apabila dibandingkan dengan taraf kepercayaan 95\% atau tingkat kesalahan 5\% dengan derajat kebebasan $(\mathrm{dk})=24-2=22$ yaitu 1,72. Dapat diketahui bahwa $\mathrm{t}$ hitung $>\mathrm{t}$ tabel yakni 4,01 > 1,72 berarti $\mathrm{H}_{1}$ diterima. Artinya, apabila guru menggunakan model pembelajaran deep dialogue critical thingking dalam proses belajar mengajar maka kemampuan pemahaman konsep siswa kelas X MIA 1 SMAN 1 Meurebo pada materi pokok persamaan nilai mutlak linier satu variable akan lebih baik. 


\section{A. Pendahuluan}

Matematika sebagai salah satu bagian dari cabang ilmu pengetahuan, mempunyai peranan yang penting dalam kehidupan sehari-hari maupun ilmu pengetahuan yang lain. Oleh karena itu pelajaran matematika selalu diberikan untuk setiap jenjang pendidikan. Matematika diberikan kepada siswa untuk membantu siswa memperoleh, mengelola dan memanfaatkan informasi untuk bertahan hidup pada keadaan yang selalu berubah dan tidak pasti. Dalam perkembangan lebih luas, konsep matematika banyak diperlukan untuk menyelesaikan masalah-masalah yang berkaitan dengan kehidupan sehari-hari.

Menurut Marpaung (Betharia, 2016) menyatakan kualitas pendidikan matematika di Indonesia dalam skala nasional masih kurang memuaskan. Hal ini terlihat pada rendahnya kualitas kemampuan matematis siswa yang tercermin dari hasil survey Internasional The Trend International Mathematics and Science Study (TIMSS) dan Programme for International Student Assesment (PISA) pada tahun 2011, Indonesia hanya menduduki urutan ke-38 dengan skor 386 dari 42 negara. Mencermati hasil tersebut sudah sepatutnya para pendidik memiliki kemampuan untuk memilih metode yang tepat dalam pembelajaran matematika, sehingga siswa dapat berperan lebih aktif selama proses pembelajaran serta dapat memahami konsep yang sedang dipelajari.

Kemampuan pemahaman ini merupakan hal yang sangat fundamental. Dengan memahami konsep siswa dapat mencapai pengetahuan prosedural matematis. Menurut Purwanto (Betharia, 2016) pemahaman adalah tingkat kemampuan yang mengharapakan siswa mampu memahami arti atau konsep, situasi serta fakta yang diketahuinya. Kemampuan memahami konsep juga dapat diartikan sebagai kemampuan menangkap pengertian-pengertian seperti mampu mengungkapkan suatu materi yang disajikan dalam bentuk lain yang dapat dipahami, mampu memberikan interpretasi dan mampu mengklasifikasinya.

Memahami konsep matematika menjadi syarat untuk dapat menguasai matematika. Pada setiap pembelajaran, selalu diawali dengan pengenalan konsep agar siswa memiliki bekal dasar yang baik untuk mencapai kemampuan dasar yang lain seperti penalaran, komunikasi, koneksi, dan pemecahan masalah. Jika pemahaman konsepnya baik, siswa tidak sekedar mengetahui atau mengingat sejumlah konsep yang dipelajari, tetapi mampu mengungkapkan kembali dalam bentuk lain yang mudah dimengerti. Siswa juga dapat memberikan interpretasi data dan mampu mengaplikasikan konsep yang sesuai dengan struktur kognitif yang dimilikinya.

Dewasa ini banyak persoalan yang dihadapi oleh guru matematika maupun oleh siswa dalam proses pembelajaran matematika. Masalah yang dimaksud antara lain siswa tidak memahami konsep matematika karena materi pelajaran yang dirasakan siswa terlalu abstrak dan kurang menarik. Hal ini sangat wajar terjadi karena metode penyampaian materi hanya terpusat pada guru sementara siswa cenderung pasif, di sisi lain siswa juga tidak diberi kesempatan berkreasi untuk menemukan sendiri kemampuan pemahaman konsep matematisnya. Siswa menjadi takut unuk mengemukakan idenya dan merasa enggan untuk mengajukan pertanyaan, meskipun guru sering meminta siswa untuk bertanya jika ada hal-hal yang belum jelas atau kurang dimengerti.

Model pembelajaran deep dialogue/critical thingking adalah model pembelajaran yang cocok pada kasus ini. Model deep dialogue/critical thingking ini dapat membantu guru untuk menjadikan pembelajaran bermakna bagi siswa, karena dalam model pembelajaran ini proses pembelajaran sebanyak mungkin terpusat pada siswa. Jadi dalam model 
pembelajaran ini siswa dilatih untuk memperoleh pengetahuan, pengalaman, menemukan konsep, dan memecahkan permasalahan melalui dialog mendalam dan berpikir kritis dengan guru dan sesama siswa. Sehingga untuk melanjutkan materi berikutnya siswa dapat dengan mudah untuk memahaminya.

Berdasarkan pembahasan yang dikemukakan di atas, penelitian ini mengarah pada pengaruh kemampuan pemahaman konsep siswa SMA terhadap model pembelajaran deep dialogue/critical thingking. Dengan begitu tujuan penelitian ini adalah: (1) Untuk mengetahui apakah terdapat pengaruh yang signifikan antara penggunaan model pembelajaran deep dialogue/critical thingking terhadap kemampuan pemahaman konsep matematika siswa kelas X SMAN 1 Meurebo; (2) Untuk mengetahui seberapa besar pengaruh antara penggunaan model pembelajaran deep dialogue critical thingking terhadap kemampuan pemahaman konsep siswa kelas X SMAN 1 Meurebo.

Pemahaman konsep terdiri dua kata pemahaman dan konsep. Menurut pendapat Tanjung (2016) kemampuan pemahaman matematika merupakan salah satu yang sangat penting dalam pembelajaran, karena bisa memberikan pengertian yang secara mendalam kepada siswa dengan materi yang diajarkan kepada bukan hanya sebagai hafalan, namun lebih dari itu dengan pemahaman siswa dapat lebih mengerti akan konsep materi pelajaran itu sendiri. Sedangkan menurut pendapat Sadiman (Betharia, 2016) yang menyatakan bahwa pemahaman atau comprehension dapat diartikan menguasai sesuatu dengan pikiran. Oleh sebab itu, belajar harus mengerti secara makna dan filosofinya, maksud dan implikasi serta aplikasi-aplikasinya, sehingga menyebabkan siswa memahami suatu situasi. Mulyasa (Harja, 2012) menyatakan bahwa pemahaman adalah kedalaman kognitif dan afektif yang dimiliki oleh individu. Sejalan dengan pendapat di atas, Ernawati (Betharia, 2016) mengemukakan bahwa yang dimaksud dengan pemahaman adalah kemampuan menangkap pengertian-pengertian seperti mampu mengungkapkan suatu materi yang disajikan dalam bentuk lain yang dapat dipahami, mampu memberikan interpretasi dan mampu mengklasifikasikannya. Rahman (2017) menyatakan bahwa konsep merupakan suatu ide abstrak yang memungkinkan seorang untuk menggolongkan suatu objek/kejadian.

Konsep matematika disusun secara berurutan sehingga konsep sebelumnya akan digunakan untuk mempelajari konsep selanjutnya. Misalnya konsep luas persegi diajarkan terlebih dahulu daripada konsep luas permukaan kubus. Hal ini karena sisi kubus berbentuk persegi sehingga konsep luas persegi akan digunakan untuk menghitung luas permukaan kubus. Pemahaman terhadap konsep materi pra- syarat sangat penting karena apabila siswa menguasai konsep materi prasyarat maka siswa lebih mudah untuk memahami konsep materi selanjutnya. Menurut Soedjadi (Umamah, 2011) konsep adalah ide abstrak yang dapat digunakan untuk menggolongkan atau mengklasifikasikan sekumpulan obyek. Sebagai contoh, segitiga adalah nama dari suatu konsep abstrak dan bilangan asli adalah nama suatu konsep yang lebih kompleks karena terdiri dari beberapa konsep yang sederhana, yaitu bilangan satu, bilangan dua, dan seterusnya. Konsep berhubungan erat dengan definisi. Definisi adalah ungkapan yang membatasi konsep. 
Dengan adanya definisi, orang dapat membuat ilustrasi atau gambaran atau lambang dari konsep yang didefinisikan, sehingga menjadi jelas apa yang dimaksud konsep tertentu.

Menurut Nasution (Umamah, 2016) siswa yang menguasai konsep dapat mengidentifikasi dan mengerjakan soal baru yang lebih bervariasi.Selain itu, apabila anak memahami suatu konsep maka ia akan dapat menggeneralisasikan suatu obyek dalam berbagai situasi lain yang tidak digunakan dalam situasi belajar. Wardhani (Kusumawati, 2017) menyatakan bahwa ada beberapa indikator yang menunjukkan suatu pemahaman konsep adalah: (1) Menyatakan ulang sebuah konsep; (2) Mengklasifikasi obyek-obyek menurut sifat-sifat tertentu (sesuai dengan konsepnya); (3) Memberi contoh dan noncontoh dari konsep; (4) Menyajikan konsep dalam berbagai bentuk representasi matematis; (5) Mengembangkan syarat perlu atau syarat cukup suatu konsep; (6) Menggunakan, memanfaatkan, serta memilih prosedur atau operasi tertentu; (7) Mengaplikasikan konsep atau algoritma pemecahan masalah. Dari indikator tersebut, maka penelitian ini mengambil beberapa indikator yang akan difokuskan yaitu: (1) Menyatakan ulang sebuah konsep; (2) Memberi contoh dan non-contoh; (3) Menyajikan konsep dalam berbagai bentuk representatif matematis. Berdasarkan beberapa pendapat di atas dapat disimpulkan bahwa pemahaman konsep adalah proses individu menguasai dengan cara menerima dan memahami informasi yang diperoleh dari pembelajaran yang dilihat melalui kemampuan bersikap, berpikir dan bertindak yang ditunjukkan oleh siswa dalam memahami definisi, pengertian, ciri khusus, hakikat dan inti atau isi dari materi matematika dan kemampuan dalam memilih serta menggunakan prosedur secara efisien dan tepat.

Deep dialogue menurut Ketut (Sekar, 2014) yang dikutip adalah kegiatan berpikir mendalam yaitu suatu kegiatan pembicaraan atau pecakapan yang terjadi antara orangorang yang berdialog harus diwujudkan dalam hubungan yang interpersonal, keterbukaan, saling jujur dan mengandalkan kebaikan. Sedangkan menurut Suyatno (Sekar, 2014) critical thingking merupakan kegiatan berpikir kritis yang dilakukan dengan mengoperasikan kemampuan intelektual untuk menganalisis, membuat pertimbangan dan mengambil keputusan dengan tepat dan benar. Berdasarkan definisi dari para ahli tersebut, dapat disimpulkan bahwa model pembelajaran deep dialogue/critical thingking ialah suatu kegiatan pembelajaran yang digunakan oleh guru dengan proses pembicaraan yang terjadi antara guru dan siswa yang harus diwujudkan dalam hubungan keterbukaan dan saling jujur dan dilakukan secara berpikir kritis dengan mengoperasikan kemampuan intelektual untuk menganalisis, membuat pertimbangan dan mengambil keputusan dengan tepat dan benar.

Menurut Sri Untari (Mila, 2016) bahwa lima komponen yang terdapat dalam model pembelajaran dengan pendekatan deep dialogue/critical thinking yakni hening, membangun komunitas, kegiatan inti dengan strategi penemuan konsep (concept attainment) dan cooperative learning, refleksi dan evaluasi. Pertama yaitu hening, yang dimaksud adalah situasi tenang sebelum pelajaran, atau dapat dilakukan dengan berdoa karena hal tersebut dapat menghadirkan hati dan pikiran siswa-guru pada pembelajaran saat itu. Kedua, membangun komunitas, yaitu menciptakan keterikatan positif sebagai satu kesatuan dengan menekankan kesamaan tujuan dan saling menghargai antar anggota. Kegiatan membangun komunitas juga merupakan sesuatu yang sangat penting bagi masyarakat 
majemuk, oleh karena itu apabila dalam pembelajaran telah dibangun keterikatan dalam komunitas kecil (kelas) maka pada skala makro, sikap dan perilaku toleransi, menghargai perbedaan, terbuka terhadap kritik, berani tampil beda, dan sikap terpuji lainnya akan dapat mengantarkan siswa menjadi warga negara yang demokratis. Ketiga, kegiatan penemuan konsep dan pembelajaran kooperatif.

Konsep merupakan struktur mental yang digunakan untuk mengorganisasikan dan mengkategorikan kenyataan. Menurut Achmad Sugandi (Mila, 2016) bahwa model pembelajaran penemuan konsep sesuai untuk menanamkan suatu konsep ilmu pengetahuan siswa dengan cara menemukan sendiri. Kegiatan ini memperhatikan prinsip "4W dan 1H", yaitu What (apa), Why (mengapa), When (kapan), Where (dimana) dan How (bagaimana), sehingga merangsang daya kritis siswa dalam memahami secara menyeluruh, menangkap permasalahan, mencari solusi permasalahan dengan caranya sendiri dan bantuan orang lain, dan mengambil keputusan yang tepat dan bermanfaat bagi diri dan lingkungannya. Keempat, refleksi, merupakan sesuatu yang dapat dipandang sebagai keunggulan pendekatan deep dialogue/critical thinking, kegiatan ini bukan menyimpulkan materi pelajaran tetapi sebagai sarana siswa untuk memberikan pendapat tentang pembelajaran yang telah dilakukan.

Menurut Nasution (Umamah, 2016) siswa merupakan faktor penting untuk menilai metode baru tersebut dan memberikan saran-saran yang berharga. Saling introspeksi baik guru maupun siswa, memberikan ungkapan bebas dan pandangan, usul terbaiknya demi kebaikan bersama. Refleksi memiliki fungsi mendidik pada siswa untuk menyukai belajar dari pengalaman yang telah dilaluinya. Kelima adalah evaluasi, seperti pendapat Daryanto (2001) bahwa evaluasi merupakan alat untuk mendapatkan informasi yang akurat mengenai tingkat pencapaian tujuan instruksional oleh siswa, sehingga guru dapat mengupayakan tindak lanjut atas pencapaian tersebut.

\section{B. Metode}

Jenis penelitian ini adalah penelitian kuantitatif. Tujuan dari penelitian kuantitatif ini yaitu untuk menunjukkan hubungan antar variabel. Penelitian ini menggunakan dua variabel yaitu variabel bebas dan variabel terikat. Variabel bebasnya yaitu model pembelajaran deep dialogue/critical thingking dan variabel terikat yaitu kemampuan pemahaman konsep matematis siswa. Desain yang digunakan dalam penelitian ini adalah pre eksperiment desaign. Desain ini digunakan untuk mengungkapkan hubungan sebabakibat hanya dengan cara melibatkan satu kelompok subjek, sehingga tidak ada control yang ketat terhadap variabel. Dalam desain pre eksperimen desaign, peneliti memakai jenisone-shot case study yaitu sebuah eksperimen yang dilaksanakan tanpa adanya kelompok pembanding dan juga tanpa adanya tes awal. Dengan desain ini peneliti tujuannya sederhana yaitu ingin mengetahui efek dari perlakuan yang diberikan pada kelompok tanpa mengindahkan pengaruh faktor yang lain.

Populasi dalam penelitian ini adalah seluruh siswa kelas X SMAN 1 Meurebo, Tahun Ajaran 2018/2019. Pada penelitian ini, peneliti mengambil sampel penelitan dengan teknik random sampling. Terpilihlah kelas $\mathrm{X} \mathrm{MIA}_{1}$ yang terdiri dari 24 orang sebagai kelas yang diteliti, yaitu kelas yang menggunakan model pembelajaran deep dialogue critical thingking. Instrumen penelitian yang digunakan meliputi: (1) lembar observasi; (2) lembar wawancara; (3) lembar tes. Tes yang akan digunakan dalam penelitian ini berupa soal uraian yang disusun berdasarkan indikator kemampuan pemahaman konsep matematis 
siswa. dengan tujuan untuk memperoleh data tentang penggunaan model pembelajaran deep dialogue/critical thingking. Tes disusun dalam bentuk uraian yang terdiri dari 9 butir soal.

Analisis statistik inferensial ialah untuk menguji apakah hipotesis yang diajukan diterima atau ditolak, maka data yang diperoleh selanjutnya digunakan teknik analisis statistik dengan rumus analisis regresi linier sederhana, koefisien deterninasi dan korelasi " $t$ " Product Moment oleh Pearson. Menurut Yuliana (2016) analisis regresi linier sederhana adalah regresi linier dimana variabel yang terikat di dalamnya hanya dua, yaitu variabel terikat $\mathrm{Y}$ dan satu variabel bebas $\mathrm{X}$. Dalam penelitian ini analisis regresi linier sederhana digunakan untuk mengetahui pengaruh model pembelajaran deep dialogue/critical thingking $(X)$ terhadap kemampuan pemahaman konsep siswa (Y). Koefisien determinasi dilambangkan dengan $r^{2}$, merupakan kuadrat dari koefisien korelasi. Koefisien ini dapat digunakan untuk menganalisis apakah variabel yang diduga (Y) dipengaruhi oleh variabel (X) atau seberapa variabel independen (bebas) mempengaruhi variabel dependen (tak bebas). Uji hipotesis dalam penelitian ini adalah korelasi " $r$ " Product Moment oleh Pearson yaitu untuk melihat apakah $\mathrm{H}_{1}$ diterima atau ditolak.

\section{Hasil dan Pembahasan}

Berdasarkan hasil analisis terhadap pretes dan kegiatan siswa dalam proses pembelajaran dengan menggunakan model pembelajaran deep dialogue/critical thingking, ternyata terdapat pengaruh yang signifikan antara kemampuan pemahaman konsep siswa terhadap model pembelajaran deep dialogue/critical thingking. Setelah didapat dari data yang telah dikumpulkan maka perhitungan melalui persamaan regresi linier sederhananya yaitu $\hat{Y}=38,45+0,52 x$. Karena pada persamaan tersebut bernilai positif maka terdapat pengaruh antara model pembelajaran deep dialogue/critical thingking terhadap kemampuan pemahaman konsep siswa.

Hasil dari perhitungan rumus koefisien determinasi dengan memasukkan nilai tes kemampuan pemahaman konsep siswa yaitu nilai $\mathrm{Y}$ dan total nilai dari kegiatan siswa selama proses pembelajaran dengan menggunakan model deep dialogue/critical thingking yaitu nilai $X$. hasil perhitungan dengan menggunakan rumus koefisien determinasi yaitu $65 \%$. Artinya bahwa model pembelajaran deep dialogue/critical thingking memiliki pengaruh yang signifikan yaitu 65\% terhadap kemampuan pemahaman konsep siswa.

Pengujian hipotesis yang ditegakkan dalam penelitian ini yaitu dengan data yang sudah dikumpulkan terlebih dahulu dilakukan perhitungan dengan menggunakan rumus yang telah ditetapkan. Hipotesis yang ditegakkan dalam penelitian ini adalah merupakan hipotesis alternatif, artinya faktor yang turut menentukan kemampuan pemahaman konsep siswa sejauh mana pengaruh penggunaan model pembelajaran deep dialogue critical thingking terhadap kemampuan pemahaman konsep siswa materi pokok persamaan nilai mutlak linier satu variabel. Hipotesis alternatif dapat diterima apabila nilai hitung $\left(\mathrm{r}_{\mathrm{xy}}\right)$ lebih besar dari nilai yang terdapat pada tabel nilai " $\mathrm{t}$ " Product Moment. Dengan taraf signifikansi 5\% pada DF (Degrees of Freedom atau derajat kebebasan) sesuai dengan jumlah subjek. Demikian juga sebaliknya hipotesis alternatif "ditolak", apabila nilai hitung $\left(\mathrm{r}_{\mathrm{xy}}\right)$ lebih kecil dari nilai yang terdapat pada tabel nilai " $\mathrm{t}$ " Product Moment. 
Hasil perhitungan yang telah dilakukan, diperoleh angka indeks t-hitung 4,01 apabila angka indeks t-hitung tersebut dibandingkan dengan nilai yang ada pada pada table " $\mathrm{t}$ ", maka dapat diketahui pada tingkat kepercayaan 95\% dengan derajat kebebasan $(\mathrm{dk})=\mathrm{n}-2=24-2=22$ diperoleh 1,72. Dengan demikian dapat diketahui bahwa nilai $\mathrm{t}$ hitung lebih besar dari t table yakni 4,01>1,72. Berdasarkan dari hasil nilai tersebut, maka $\mathrm{H}_{1}$ dalam penelitian ini dapat diterima atau disetujui. Artinya dengan menggunakan model pembelajaran deep dialogue/critical thingking yang dilakukan guru dapat mempengaruhi kemampuan pemahaman konsep siswa pada materi pokok persamaan nilai mutlak linier satu variabel.

\section{Kesimpulan}

1. Setelah didapat nilai $a$ dan $b$ maka persamaan regresi liniernya yaitu $\hat{Y}=38,45+0,52 x$. Artinya pada kemampuan pemahaman konsep siswa jika menggunakan model pembelajaran deep dialogue critical thingking maka kemampuan pemahaman konsep siswa akan menjadi lebih baik dari sebelumnya. Sedangkan hasil perhitungan dengan menggunakan korelasi product moment didapat nilai t hitung 4,01. Apabila dibandingkan dengan taraf kepercayaan 95\% atau tingkat kesalahan 5\% dengan derajat kebebasan $(\mathrm{dk})=24-2=22$ yaitu 1,72. Dapat diketahui bahwa t hitung $>\mathrm{t}$ tabel yakni 4,01 >1,72 berarti $\mathrm{H}_{\mathrm{a}}$ diterima atau disetujui. Artinya terdapat pengaruh yang signifikan antara penggunaan model pembelajaran deep dialogue/critical tingking terhadap kemampuan pemahaman konsep siswa kelas $\mathrm{X} \mathrm{MIA}_{1}$ SMAN 1 Meurebo.

2. Pengaruh antara penggunaan model pembelajaran deep dialogue/critical thingking terhadap kemampuan pemahaman konsep siswa yaitu sebesar 65\%. Hasil tersebut didapat dari perhitungan rumus koefisien determinasi dengan memasukkan nilai tes kemampuan pemahaman konsep siswa yaitu nilai $\mathrm{Y}$ dan total nilai dari kegiatan siswa selama proses pembelajaran dengan menggunakan model $\mathrm{dd} / \mathrm{ct}$ yaitu nilai $\mathrm{X}$ maka koefisien determinasinya yaitu $65 \%$.

\section{Daftar Pustaka}

Betharia, R. (2016). Pengaruh Pembelajaran Kooperatif Tipe Think Pair Share Terhadap Pemahaman Konsep Matematis Siswa. Skripsi Tidak Diterbitkan FPMIPA UPI (tidak dipublikasikan).

Harja. (2012). Pemahaman Konsep Matematis. Jurnal Ilmiah. Vol 4 (3): 11.

Kusumawati, W. (2017). Kajian Teoritik. Jakarta: PT Rineka Cipta.

Mila, Z. (2016). Model Pembelajaran Deep Dialogue Critical Thingking.Jurnal Ilmiah. Vol 12 (3): 22.

Rahman, A.A. (2017). Penerapan Pendekatan Realistic Mathematic Education (RME) Pada Materi Statistika untuk Meningkatkan Pemahaman Konsep dan Prestasi Belajar Siswa. Maju: Jurnal Pendidikan Matematika. Vol VIII(2): 2. 
Sekar, C. (2014). Model Pembelajaran Deep Dialogue Critical Thingking. Jakarta: Av Publisher.

Tanjung, H.S. (2016). Peningkatan Kemampuan Pemahaman dan Komunikasi Matematik Siswa Sekolah Menengah Atas (SMA) melalui Model Pembelajaran Kooperatif. Maju: Jurnal Pendidikan Matematika, Vol III (2): 59.

Umamah, N. (2016). Model Pembelajaran Deep Dialogue Critical Thingking. Jakarta: Av Publisher. 